\title{
Development of Character Values through Entrepreneurship in Forming Independence and Anti Corruption at Serambi Mekkah University
}

\author{
Hayati ${ }^{1}$, Eka Mayasari ${ }^{2}$, Ismawirna ${ }^{3}$, Rahmadon $^{4}$ \\ \{hayati@gmail.com ${ }^{1}$ \}

\begin{abstract}
${ }^{1}$ Islamic Faculty Lecturer at Serambi Mekkah University Banda Aceh, Indonesia
${ }^{2}$ Lecturer at the Faculty of Islamic Studies, Serambi Mekkah University, Banda Aceh, Indonesia

${ }^{3}$ Lecturer of FKIP Serambi Mekkah University Banda Aceh, Indonesia
\end{abstract} \\ ${ }^{4}$ Lecturer of the Faculty of Islamic Studies, Serambi Mekkah University, Banda Aceh, Indonesia
}

\begin{abstract}
This research aims to develop character values through Entrepreneurs hip activities in forming independence and anti-corruption in students of Serambi Mekkah University Banda Aceh. "The long-term goal of this research is to realize college graduates who have an independent spirit and anticorruption behavior. While the specific purpose of this study is to give birth to the concept of character with a learning approach ( holistic learning method) Entrepreneurship that is easy to understand by students in fostering an entrepreneurial spirit and anticipating corruption behavior. This research method uses the approach (mix method). The design of this study was carried out in two stages. In the first phase, a survey of methods and approaches will be conducted as input in developing integrated character learning methods using an Entrepreneurship approach involving students and lecturers. In the second phase, a trial was conducted to develop entrepreneurship learning in the field. The total population of this research is all students in the Serambi Mekkah University in Banda Aceh which consists of 6 (Six Faculties), namely 600 students of 2014. While the sample $(10 \%)$ of the total population is 60 people. The sampling technique is done in a way purposive sampling. The results of the study obtained a shift in the value of the character of students and lecturers before and after testing in entrepreneurship, including the value of honesty, discipline, hard work, and commitment. $50 \%$ of respondents were unable to meet the time between college and work, $20 \%$ of respondents were not good at finding suitable opportunities in business , $60 \%$ of respondents did not have talent in doing business, $68 \%$ of respondents still had a mindset to become a civil servant $.5 \%$ of respondents were unable to finish their studies on time. $M$ students who have successfully run their businesses have been able to complete their studies on time for 4 years, 2 of whom obtained coumloude achievements. Character values that develop from entrepreneurship to students of the Veranda of Mecca University are, values of honesty, hard work, cooperation, discipline, hospitality, patience, sincerity, help, commitment and risk taking.
\end{abstract}

Keywords: Implementation, Integrity, Entrepreneurship. 


\section{Introduction}

One of the efforts taken by the government in eradicating corruption is through formal education in universities, because Higher Education is one of the means that is considered refresentatif in tackling various acts of crime including in preventing corruption.

The subjects applied in the higher education institutions that are being promoted are entrepreneurship. Considering that every year a college produces new graduates, if it is not equipped with entrepreneurship, then the college graduates will create high levels of unemployment which will lead to the occurrence of various crimes and the possibility of corruption.

Given that employment is now increasingly difficult, the employment of civil servants through the PNS line is also increasingly narrow, while there are college personnel who are still middle to lower-income economics. [1] states that "the role of the leader as a motivator in moving students and lecturers in entrepreneurship is expected."

With the provision of lecturer skills as a manager in the field of entrepreneurship, it is expected to be able to foster working spirit in various fields through campus cooperative channels. This means that universities provide a forum to accommodate all the creativity of lecturers, employees and all college personnel, so that the welfare of subordinates is increasing. The purpose of this research is to see whether the character values taught through theory so far can be applied directly by students and lecturers in the field.

\section{Methodology}

This study uses descriptive qualitative and quantitative methods (mix method), qualitative research approach steps are carried out through observation, interviews, and documentation studies. While the quantitative approach is done with a Likert scale. First determine the course to be developed. The second phase of the courses identified syllabus di kembangkan. Tahap to three a lesson plan development phase to foster the spirit of the characters entrepreneurship, independence and anti-corruption. Tahap into four, namely the development of character values into the view of entrepreneurship learning. The five stages of testing the application of learning products Entrepreneurship. At the time of the trial the researcher provided a business capital of $\mathrm{Rp} .1000,000$, - (one million rupiah) as business capital. However, this capital is returned to the researcher in accordance with the schedule / time agreed between capital owners and entrepreneurs. While the profits are all owned by businesses, this is done to avoid the reason students do not have business capital.

\subsection{Entrepreneurship Goals (Entrepreneurship)}

Entrepreneurial activities are not only understood to open employment opportunities or independent work, but broader than that entrepreneurial activity is a collaborative process of various knowledge and abilities in driving a business. The same thing as stated by [2] entrepreneurship can be interpreted as a momentum to change mentality, mindset and sociocultural changes. Thus it can be concluded that entrepreneurship is the ability to see and seek opportunities in optimizing all the potential of themselves in achieving goals.

Entrepreneurship education is a planned and applicative effort to increase knowledge, intentions and intentions and the ability of students to develop their potential by being manifested in creative, innovative and daring behavior in managing Ade [3]. 
From the description above, it can be concluded that the purpose of entrepreneurship is not only to open new jobs, but more broadly than to explore self-potential and adjust it to the needs of the job market and be able to move others in meeting their needs.

\subsection{Value of Entrepreneurship}

Every entrepreneur must have a concept called basic values that must be possessed every entrepreneur. According to [4] the basic values that must be held important to entrepreneurs are: Creativity, innovation, dare to take risks, responsibilities, hard work, and have ethics and morals. While [5] mentions, there are several values that are general in nature which can be seen as characteristics of successful entrepreneurship, namely: 1) the desire to produce products, 2). Quality service to consumers, 3). Flexible 4), ability in management 5). Have courtesy and ethics, 6). Trying to create opportunities by generating courage.

To become a successful entrepreneur, very high internal motivation is needed. According to [6] the motivation of entrepreneurship is the attention, pleasure, and willingness of a person to carry out independent business activities based on their abilities, strengths and skills. It is this motivation that directs and moves a person to build his own business. To develop the character values of students through entrepreneurship activities it is necessary to conduct trials in the field both in the form of individuals and in the form of groups in the field.

The concept of entrepreneurship learning is expected to give birth to graduates who have character values. As amended by (Ministry of National Education, 2010: 10-11)

These values can be developed as follows:

1) Mandiri is an attitude and behavior that is not easily dependent on others in completing tasks

2) Creative is thinking and doing something to produce different ways or results from existing products / services

3) Dare to take risks is the ability to like work that is challenging, brave and able to take the risk of work

4) Oriented to action is to take the initiative to act, and not wait, before an undesirable event occurs

5) Leadership is an attitude and behavior that is always open to suggestions and criticisms, easy to get along with, prudent and allow others

6) Hard work is a behavior that shows genuine effort in completing tasks and overcoming various obstacles.

7) Honest is a behavior based on the effort to make himself a person who can always be trusted in words, actions and work.

8) Discipline is an act that demonstrates certain disciplinary behavior and is compliant with various rules and regulations

9) Innovation is the ability to apply creativity in order to break problems opportunities to enhance and enrich life

10) Responsibility is attitude and behavior that is willing and able to carry out their duties and obligations.

11) Cooperation is behavior based on efforts to make himself able to establish relationships with others in carrying out actions and work.

12) Never give up are attitudes and behaviors that are not easy to give up to achieve a goal with various alternatives

13) Commitment is an agreement about something that is made by someone, both for themselves and for others 
14) Realistic is the ability to use facts / reality as a basis for rational thinking in every decision making or action / action

15) Curiosity is an attitude and action that always strives to know deeply and broadly from what is learned, seen, and heard.

16) Communicative is an act that shows the pleasure of talking, associating, and collaborating with others.

17) The strong motivation for success is the attitude and action are always looking for the best solution.

\section{Results And Discussion}

\subsection{Result}

Character values developed from the activities of entrepreneurship at the University of the Veranda of Mecca is:

\begin{tabular}{|c|c|c|}
\hline No. & Character Value & Description \\
\hline 1 & Istiqamah, & $\begin{array}{l}\text { Istiqamah which is meant in this paper is the determination and } \\
\text { unanimity of the thoughts and feelings of entrepreneurs in carrying out } \\
\text { their business by asking for the pleasure of Allah Almighty. }\end{array}$ \\
\hline 2 & Resignation, & $\begin{array}{l}\text { Submitting fully to God the results that have been implemented and } \\
\text { accepting whatever decisions and results obtained will beaccepted by } \\
\text { students sincerely. }\end{array}$ \\
\hline 3 & Honesty & $\begin{array}{l}\text { Honesty is one of the obligatory characteristics of the Prophet who needs } \\
\text { to be imitated and exemplified by every Muslim. Honest } \\
\text { entrepreneurship not only produces satisfaction for the seller, but also } \\
\text { gives the buyer confidence. Familiarizing yourself with oneself also } \\
\text { affects others, because honesty in entrepreneurship will not harm } \\
\text { others. Honestly what is meant is"do not expect praise and judgment } \\
\text { from other people, but he feels always under the supervision of God } \\
\text { Almighty". Honest in an entrepreneur is saying everything as is. the } \\
\text { effort that is done does not violate the Shari'ah and is truly lawful. So } \\
\text { that whatever is attempted does not damage consumers or others. }\end{array}$ \\
\hline 4 & Patience, & $\begin{array}{l}\text { Patience is also a part of noble character, without patience all efforts will } \\
\text { experience destruction. In addition to the integrity values above, other } \\
\text { values that can be developed fromentrepreneurship activities } \\
\text { are : Emandirian K, K etangguhan, Keteladanan, T awakkal. Islam } \\
\text { really appreciates every effort that is carried out both individually and } \\
\text { in groups. }\end{array}$ \\
\hline 5 & Hard work & $\begin{array}{l}\text { Successful entrepreneurs, beginning with hard work. No hard work is } \\
\text { difficult to realize an ideal in developing its business.Entrepreneurs do } \\
\text { not know tired and desperate in trying. }\end{array}$ \\
\hline 6 & sincere, & $\begin{array}{l}\text { A sincere attitude is an attitude that is not visible from someone's outer } \\
\text { behavior, but it is an inner attitude that is very deep and can be felt by } \\
\text { others. }\end{array}$ \\
\hline 7 & clean, & $\begin{array}{l}\text { People who have a superior entrepreneurial spirit are able to give birth to } \\
\text { a clean attitude, because whatever activities are carried out without a } \\
\text { clean element, both physically and mentally, it is difficult to develop. }\end{array}$ \\
\hline 8 & frugal & Savings behavior is obtained from the habit of managing finances well, \\
\hline
\end{tabular}




\begin{tabular}{lll}
\hline No. & Character Value & \multicolumn{1}{c}{ Description } \\
\hline 9 & & with the spirit of entrepreneurship saving behavior easily formed. \\
9 & Commitment & The entrepreneur's ability to be firm and serious. \\
10 & Discipline & Able to manage time between college and business. \\
\hline
\end{tabular}

Evaluation of the development of character values is carried out including evaluation of knowledge and measurement of motivation for entrepreneurship. Developing character value before uj i try and after testing is very different entrepreneurship. The theoretical assessment of the values of entrepreneurial character in students is generally good, but after testing the values of student character began to shift, including: the value of discipline, the value of honesty, diminishing commitment. 50\% of respondents can not afford to time between college and work, $20 \%$ of respondents are not good at finding suitable opportunities in the business around campus , $60 \%$ of respondents do not have talent in doing business , $68 \%$ of respondents stick to the mindset of being a civil servant , $5 \%$ of respondents are unable to complete college on time because busy entrepreneurship.

For more details, the implementation of entrepreneurship activities at Serambi Mekkah University can be seen in the following table:

\begin{tabular}{|c|c|c|}
\hline No. & Faculty & Results of Entrepreneurship Activities \\
\hline \multirow[t]{5}{*}{1} & Tarbiyah & Mushroom cultivation \\
\hline & & Cut chicken \\
\hline & & Broking trade \\
\hline & & Grap (online motorcycle taxi) \\
\hline & & Online clothing business \\
\hline \multirow[t]{5}{*}{2} & Economy & Trade while studying \\
\hline & & Open stalls for kiosks to trade credit \\
\hline & & And other snacks. \\
\hline & & Business making on line \\
\hline & & Salted fish processing \\
\hline \multirow[t]{6}{*}{2} & FKIP & Manufacture Cilimeng y ang derived from sunti acid (has got \\
\hline & & IPR) from the department of Chemistry \\
\hline & & Dish soap from Chemistry Study Program \\
\hline & & Beet syrup from the Chemistry Study Program \\
\hline & & Development of hydroponic vegetable cultivation from Biology \\
\hline & & Study Program \\
\hline \multirow[t]{3}{*}{3} & Agriculture & $\begin{array}{l}\text { - Development of kemamah fish from food product technology study } \\
\text { program }\end{array}$ \\
\hline & & $\begin{array}{l}\text { Making salted fish without preservatives from food yield } \\
\text { technology }\end{array}$ \\
\hline & & Making preservatives without preservatives from food technology \\
\hline 4 & FKM & Making rambutan seeds as a cure for diabetes. \\
\hline \multirow[t]{2}{*}{5} & Technique & Making vinegar from durian skin \\
\hline & & Making perfume aroma therapy \\
\hline
\end{tabular}

From the table above, it can be seen that many entrepreneurship activities carried out are from the Faculty (FKIP) and (Engineering), while others are still very minimal. The level of integrity owned by students and lecturers in developing their research products can be said to be very good, this is evidenced from the fact that each product produced by students and lecturers does not contain elements that are harmful to the health of the body, especially from the results of food or beverage products. From the entrepreneurship activities developed at the 
Serambi Mekkah University, young entrepreneurs have opened up new jobs, such as cafes, restaurants etc.

\subsection{Discussion}

Indonesia is one of the countries that has the most educated unemployment rates . This educated unemployment will be disastrous if it is not taken seriously by the government. As educated people, motivating entrepreneurship does not have to be moved by others. One must create and know the interests and talents in him. According to [7], interest is a sense of preference and a sense of interest in something or activity, without anyone telling. Pe interest is basically an acceptance of something and other relationship with the outside world. Another thing stated by [8] the low interest of someone to entrepreneurship becomes a serious thought both government, educational institutions and the business world.

In developing entrepreneurship in universities, it can be done through various techniques, including:

1. Through integration with all courses

Teaching material is a learning component that is very influential on what actually happens in the learning process. Many lecturers who teach merely follow the order of presentation and learning activities that have been designed by the textbook writer. Even though the integration of entrepreneurial values can be carried out in teaching materials both in material presentation, assignments and evaluations.

2. Entrepreneurship education occurs in extracurricular activities

In extracurricular activities lecturers can conduct entrepreneurial activities individually or in groups.

3. Entrepreneurship education through self-development.

Self-development activities can be carried out in channeling students' interests and talents according to their expertise, such as making bazaars, business days, developing works of students and lecturers in the form of writing and so on.

4. Entrepreneurship education from theory to practice. Entrepreneurship activities are not only carried out in theory but also applied in employment.

5. Entrepreneurship education through local content

Of all the concepts of entrepreneurship learning above are expected to give birth to graduates who have character values. As amended by (Ministry of National Education, 2010: 10-11)

\section{Conclusion}

Development of character values through activities entrepreneurship at Serambi Mekkah University has not received satisfactory results. This is due to the very diverse background of entrepreneurship subject lecturers, the lack of a number of linear entrepreneurship subject lecturers. Of course the development of e ntrepreneurship many students who successfully complete their studies at their own expense and hard work of the students, a proportion of students are not able to complete their studies because it is not able to divide time a ntara college and work. This shows that the values that are possessed by students have not been able to be applied in every effort they make. To find out that every entrepreneur is able to develop good entrepreneurship, it must be done with repeated trials, so that they have adequate experience. 


\section{References}

[1] A. S. Nugraheni, "the role of the principal as a motivator in moving students and teachers in entrepreneurship is expected." 2016.

[2] B. R. Purnomo, "Effectiveness of Entrepreneurship Training in Improving Entrepreneurial Knowledge and Motivation for Deaf Persons," J. Manag. Bus., vol. 1, no. 1, pp. 21-30, 2017.

[3] A. Suyitno, Entrepreneurship Education, Teri \& Practice. Jakarta: Gramedia, 2013.

[4] B. Alma, Entrepreneurship for Students and the Public. Bandung: Alfabeta, 2008.

[5] Hisrich, Entrepreneurship, 6th ed. Boston: Mc Grow Hill, 2005.

[6] Herawaty, "Entrepreneurial Motivation," 2010.

[7] Slameto, Learning and its influential factors. Jakarta: Rineka Cipta, 2003.

[8] Nurikasari, "The Effect of Entrepreneurship Education, Creativity, and Entrepreneurial Motivation on Entrepreneurial Interest in Kanjuruhan University Economic Education Students Malan," J. Econ. Educ. Res., vol. 1, no. 2, 2016. 